\title{
The endocannabinoid pathway and the female reproductive organs
}

\author{
Anna Maria Di Blasio, Michele Vignali ${ }^{1}$ and Davide Gentilini \\ Molecular Biology Laboratory, Istituto Auxologico Italiano, Via Zucchi 18, 20095 Cusano Milanino, Milano, Italy \\ ${ }^{1}$ Department of Obstetrics and Gynecology, University of Milano, Milano, Italy
}

Correspondence

should be addressed to

A M Di Blasio

Email

a.diblasio@auxologico.it

\begin{abstract}
Endocannabinoids are endogenous ligands of cannabinoid, vanilloid and peroxisome proliferator-activated receptors that activate multiple signal transduction pathways. Together with their receptor and the enzymes responsible for their synthesis and degradation, these compounds constitute the endocannabinoid system that has been recently shown to play, in humans, an important role in modulating several central and peripheral functions including reproduction. Given the relevance of the system, drugs that are able to interfere with the activity of endocannabinoids are currently considered as candidates for the treatment of various diseases. In this review, we will summarise the current knowledge regarding the effects of endocannabinoids in female reproductive organs. In particular, we will focus on some newly reported mechanisms that can affect endometrial plasticity both in physiological and in pathological conditions.
\end{abstract}

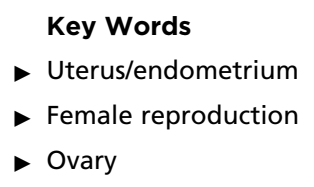

Journal of Molecular

Endocrinology

(2013) 50, R1-R9

\section{Introduction}

Endocannabinoids are endogenous ligands that bind to the same receptors as the principal biologically active component of Cannabis sativa, $\Delta^{9}$-tetrahydrocannabinol ( $\Delta^{9}$-THC). $\Delta^{9}$-THC and its related molecule $\Delta^{8}$-THC exert their central psychoactive effects acting through the cannabinoid receptor CB1, while their peripheral effects are mostly mediated by the cannabinoid receptor CB2 (Matsusa et al. 1990, Munro et al. 1993). However, some peripheral tissues express both receptor isotypes (Zygmunt et al. 2000). The effects of exogenous cannabinoids on human fertility have been extensively studied in marijuana smokers, and it has been clearly demonstrated that, at high doses, they can alter trophoblast development and invasiveness, oviductal transport, prostaglandin production by human gestational tissues and endometrial decidualisation (Kessler et al. 2005, Wang et al. 2006, Mitchell et al. 2008). Recent studies have underlined that endocannabinoids, under the control of sex hormones and cytokines, mimic similar effects in female reproduction (Karasu et al. 2011). In this review, we will summarise the importance of the endocannabinoid system in female reproductive organs and will point out new mechanisms affecting endometrial plasticity.

\section{The endocannabinoid pathway}

$\mathrm{N}$-arachidonoylethanolamine (anandamide, AEA) and 2-arachidonoylglycerol (2-AG) are the principal endocannabinoids and act primarily at cannabinoid receptors $\mathrm{CB} 1$ and $\mathrm{CB} 2$. Additional endocannabinoids have also been discovered. They either activate the same receptors or potentiate the effects of AEA and 2-AG by inhibiting their degradation (Ho et al. 2008). In addition, AEA also binds to type 1 vanilloid receptor (TRPV1; Starowicz et al. 2007) and to peroxisome proliferator-activated receptor $\gamma$ (PPAR $\gamma$; Gasperi et al. 2007). AEA and 2-AG together

Published by Bioscientifica Ltd. 
with other cannabinoid-like compounds, their metabolic enzymes, the target receptors and the putative membrane transporter form the endocannabinoid system.

\section{Synthesis, transport and degradation}

Endocannabinoids are synthesized on demand from phospholipid precursors and are not stored (Habayeb et al. 2002). AEA is formed by cleavage of its precursor $\mathrm{N}$-arachidonoyl phosphatidylethanolamine (NAPE) into AEA and phosphatidic acid by NAPE-hydrolysing phospholipase D (NAPE-PLD), which is a calcium-sensitive enzyme (Okamoto et al. 2004, Wang et al. 2006). Alternative pathways for AEA synthesis also exist. They include hydrolysis of NAPE by phospholipase $\mathrm{C}$ to form phospho-AEA, which is then dephosphorylated by a protein tyrosine phosphatase (Liu et al. 2006) or acyl hydrolysis of NAPE to form glycerophospho-NAPE subsequently hydrolysed to AEA by a phosphodiesterase (Simon \& Cravatt 2006). 2-AG is also released on demand after conversion of diacylglycerol by a diacylglycerol lipase (Prescott \& Majerus 1983).

The biological activity of endocannabinoids is regulated by fine mechanisms of intracellular uptake and degradation to free arachidonic acid. The principal enzymes involved are serine hydrolase's fatty acid amide hydrolase (FAAH) and monoacylglycerol lipase for AEA and 2-AG respectively (Ligresti et al. 2005, McKinney \&
Cravatt 2005). Additional degradation mechanisms catalysed by lipoxygenase (van der Stelt et al. 2002), cyclooxygenase-2 (Rouzer \& Marnett 2008) or cytochrome P450 (Snider et al. 2008) have also been demonstrated. By contrast, AEA transport through the plasma membrane has not been fully elucidated yet. Most likely, it is catalysed by a carrier protein that also takes up 2-AG (Battista et al. 2005, Hermann et al. 2006). However, diffusion driven by FAAH (Day et al. 2001), diffusion driven by compartmentalisation of intracellular AEA (Hillard \& Jarrajan 2003) and endocytosis (McFarland et al. 2004) have been hypothesised.

\section{Signal transduction and biological activity}

AEA and 2-AG exert most of their biological effects by binding to the cannabinoid receptors CB1 and CB2. These are seven-transmembrane G-protein-coupled receptors that share 44\% homology (Howlett et al. 2002). Initially, CB1R was isolated in the rat brain (Devane et al. 1988) and CB2R in the rat spleen and human myeloid cells (Munro et al. 1993), but it is now known that both of them are present in the CNS and several peripheral tissues (Karasu et al. 2011). A new putative cannabinoid receptor, CB3 or GPR55, has been recently identified (Lauckner et al. 2008), but its biological significance has not been completely elucidated (Ross 2009). As illustrated in Fig. 1, ligand binding of $\mathrm{CB}$ receptors activates several signalling

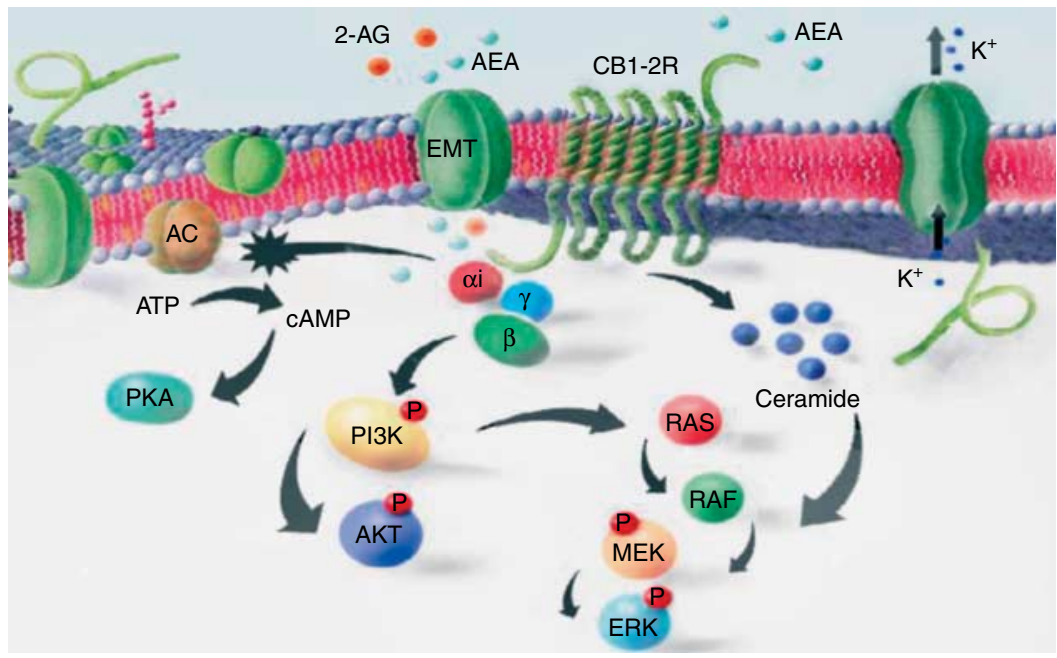

\section{Figure 1}

Overview of the most important biochemical pathways for cellular uptake and biological actions of the endogenous cannabinoids. Cannabinoids produce their effects by binding to specific G-protein-coupled plasma membrane receptors that can inhibit adenylate cyclase (AC); activate PKA,
PI3K, AKT and MAPK; increase $\mathrm{K}^{+}$currents and stimulate ceramide production. Intracellular degradation is achieved following their transport through the plasma membrane mediated by the endocannabinoid membrane transporters (EMT). http://www.jme.endocrinology-journals.org DOI: 10.1530/JME-12-0182
(C) 2013 Society for Endocrinology Printed in Great Britain
Published by Bioscientifica Ltd 
pathways leading to reduced intracellular cAMP concentrations, activation of MAP kinases, regulation of ionic current and activation or inhibition of inducible nitric oxide synthase (Diaz-Laviada \& Ruiz-Llorente 2005).

The multiple signal transduction pathways activated by endocannabinoids underlie the different biological activities exerted within the CNS and the peripheral tissues. At the central level, endocannabinoids modulate pain initiation, psychomotor behaviour, memory, thermogenesis and appetite (Katona \& Freund 2008), while in the periphery, they act on the immune (Klein 2005), cardiovascular (Pacher et al. 2008) and reproductive system (Maccarrone 2009) as well as on energy balance (Pagotto et al. 2006). Additional effects on pain transmission are mediated by binding to TRPV1 (Huang et al. 2002), while modulation of lipid and glucose metabolism is achieved by activation of PPAR $\gamma\left(\mathrm{O}^{\prime}\right.$ Sullivan 2007).

\section{The endocannabinoid system and the ovary}

In the ovary, the endocannabinoid system has been poorly investigated, but the observations that, in humans, plasma AEA concentration increases in the natural menstrual cycle at the time of ovulation have stimulated researchers on this peculiar topic (Nir et al. 1973). Recently, it has been reported that the entire endocannabinoid system is active at the ovarian level and CB1R and CB2R, NAPE-PLD and AEA, have been identified in ovarian tissue (El-Talatini et al. 2009). Immunostaining shows expression of CB1R and $\mathrm{CB} 2 \mathrm{R}$ in the medulla and cortex of the ovary. In the cortex, the receptors are expressed in the granulosa cells of primordial, primary, secondary and tertiary follicles and in the theca cells of secondary and tertiary follicles. Both receptors have also been observed in the corpus luteum and corpus albicans. NAPE-PLD, on the other hand, is expressed in the granulosa and theca cells of secondary and tertiary follicles, in the corpus luteum and in the corpus albicans, suggesting that AEA is mainly produced from the granulosa of growing follicles but not from oocytes (El-Talatini et al. 2009).

The changes in reproductive functions induced by cannabis derivatives strongly suggest that they exert potent negative effects on the ovulatory cycle. The primary negative effects are ascribed to a hypothalamic action, although some of these down-regulating influences may be mediated directly at the level of the pituitary and the ovary. At systemic level, cannabinoids are able to modulate the hypothalamic-pituitary-gonadal axis and they have been shown to down-regulate blood $\mathrm{LH}$ levels, by indirectly modifying GNRH secretion (Murphy et al. 1990). In vitro studies on rats have also demonstrated that $\Delta^{9}$-THC exerts a direct inhibitory effect on both folliculogenesis (Adashi et al. 1983) and ovulation (El-Talatini et al. 2008). In support of these findings, in humans, a direct adverse effect on the ovary has been clearly documented, as cannabis users are at a higher risk of primary infertility due to anovulation (Mueller et al. 1990), and when they undergo IVF treatment, they produce poor-quality oocytes and have lower pregnancy rates compared with non-users (Klonoff-Cohen et al. 2006). Moreover, follicular fluid AEA concentrations are correlated with follicle size and are lower in follicles from which oocytes are not retrieved, indicating that AEA is probably involved in the maturation of the follicles and the oocytes (Schuel et al. 2002, El-Talatini et al. 2007, 2009).

It is well known that the endocannabinoid system regulates energy balance by modulating appetite, food intake and glucose metabolism (Bellocchio et al. 2007, Nogueiras et al. 2009). Some evidence also suggests that the endocannabinoid system could interact with ovary function through the modulation of pathways involved in energy balance and metabolism control. Indeed, obesity is commonly associated with menstrual irregularities, chronic oligo-anovulation and infertility (Pasquali et al. 2007), and regular ovulation is restored after simple management strategies aimed at weight reduction leading to improved natural conception (Zain \& Norman 2008, Wilkes \& Murdoch 2009).

Intriguingly, some authors suggested that there are several possibilities that specific, still undefined dysfunctions of the endocannabinoid system may be implicated in some pathological condition such as polycystic ovary syndrome (PCOS), which affects the ovary (Gambineri et al. 2004, Pasquali et al. 2006). PCOS is one of the most common causes of infertility due to anovulation in women. The disease is characterised by oligo- and/or anovulation, clinical and/or biochemical signs of hyperandrogenism and presence of polycystic ovaries. It is important to underlie that cardinal features of PCOS such as insulin resistance, androgen hypersecretion and obesity might be influenced by the endocannabinoid system. In rats, it has been shown that AEA activation of CB1R in pancreatic $\beta$ cells can induce insulin hypersecretion and insulin resistance (Bermudez-Siva et al. 2006, Ahren 2009). These observations suggest that a local effect of endocannabinoid signalling in the pancreas might also play a role in PCOS-associated insulin resistance. Finally, PCOS anovulation may be, at least in part, the result of the complex interplay that exists between endocannabinoids, leptin production and obesity (Battista et al. 2008).

Published by Bioscientifica Ltd. 
However, further studies are mandatory to disentangle the relative contribution of endocannabinoids, local and systemic effects in the aetiopathogenesis of PCOS.

\section{Endocannabinoid and the oviduct}

The transport of the embryo from the oviduct to the uterus is aided by a wave of regulated contraction and relaxation of the oviduct muscularis. It is thought that the sympathetic neuronal circuitry, under the direction of ovarian hormones, coordinates the 'closing and opening' of the sphincter at the isthmus-uterine junction, thereby regulating the timely passage of embryos from the oviduct into the uterus (Howe \& Black 1973, Heilman et al. 1976). It has been reported that CB1R and CB2R knockout mice are characterised by a high level of pregnancy loss (Wang et al. 2006). CB1R is colocalised with $\alpha 1$ - and $\beta 2$-adrenergic receptors (AdRs) in mouse oviductal muscularis at the isthmus region, and the $\beta$-AdR agonist isoproterenol restores normal embryo transport in CB1R knockout mice (Wang et al. 2004). These results indicate that maternal expression of CB1R in the reproductive tracts plays a fundamental role in ensuring normal embryo transfer from the oviduct to the uterus. Interestingly, wildtype females exposed to a stable AEA analogue (methanandamide) or natural THC also show pregnancy loss with embryo retention in the oviduct (Wang et al. 2006). These observations suggest that either a silenced or an enhanced cannabinoid signalling may influence embryo transport.

\section{Endocannabinoid and the uterus}

In the uterus, the endometrium represents a significant source of endogenous cannabinoids, and AEA levels are higher than in other reproductive tissues (Das et al. 1995, Schmid et al. 1997). The expression of the individual components of the endocannabinoid system was initially demonstrated in mice uteri (Das et al. 1995, Paria et al. $1999,2001)$ and then also in humans, with both species expressing similar AEA levels (Taylor et al. 2010a). According to Taylor et al. (2010a) CB1R immunoreactivity is more intense in the glandular epithelium compared with the stroma and its expression is not regulated throughout the menstrual cycle. These findings were not confirmed by Resuehr et al. (2012) who recently reported a dramatic increase in CB1R mRNA and protein in normal endometrial samples in the secretory phase likely due to progesterone modulation. CB2R immunoreactivity is found in both glands and stroma; its expression is minimal at the beginning of the cycle and reaches a peak during the late proliferative phase (Taylor et al. 2010a). NAPE-PLD is intensively expressed in the menstrual, early-proliferative and late secretory glands with its lowest levels in the earlysecretory phase. This enzyme is also found in the stroma (Taylor et al. 2010a). Glandular expression of FAAH increases during the menstrual cycle reaching a peak during menstruation. Similarly, FAAH is also expressed in the stroma (Taylor et al. 2010a). The expression of these two enzymes in the endometrium suggests that, during the menstrual cycle, they modulate AEA concentrations that are lower in the mid-luteal phase consistent with the idea that low levels are beneficial, and high levels detrimental, to blastocyst development (Maccarrone et al. 2002, Taylor et al. 2010b).

The human endometrium is a plastic tissue in which cells undergo a variety of adaptation reactions in response to the physiological changes that occur during the menstrual cycle and embryo implantation (Salamonsen 2003). Endometrial cell migratory behaviour can be considered as a central feature of endometrial plasticity and crucial for endometrial physiology. The stromal component begins to grow when the endometrial wound is completely re-epithelialised and endometrial cell movements are essential to repopulate the space created by tissue loss and to avoid excessive fibroplasia. These events are mainly regulated by steroid hormones, the timing and concentrations of which dictate the balance between endometrial growth and transformation (Guzeloglu-Kayisli et al. 2004). Interestingly, recent data support the idea that the endocannabinoid system plays an important role in the control of endometrial plasticity by regulating endometrial cell motility (Gentilini et al. 2010). We demonstrated for the first time that methanandamide stimulates endometrial stromal cell migration in a dose-dependent manner (Fig. 2) via CB1R and not via $\mathrm{CB} 2 \mathrm{R}$ activation as indicated by the $\mathrm{CB} 1 \mathrm{R}$ antagonist AM251-selective inhibition. This effect is mediated by activation of ERK1/2 and PI3K/Akt pathways as selective inhibitors of both pathways can prevent the stimulatory effect of methanandamide whereas inhibition of adenylate cyclase is probably not involved.

The protein-protein interactions and signalling events that regulate cell migration involve cytoskeleton rearrangement and formation of different actin structures indispensable for cell movements (Anand-Apte \& Zetter 1997, Alessandro \& Kohn 2002, Friedl \& Wolf 2003). In agreement with these mechanisms, methanandamide activation of ERK1/2 and PI3K/Akt in endometrial stromal cells is able to induce rapid changes in the cytoskeleton architecture of the cells that thus acquire a migratory

Published by Bioscientifica Ltd. 

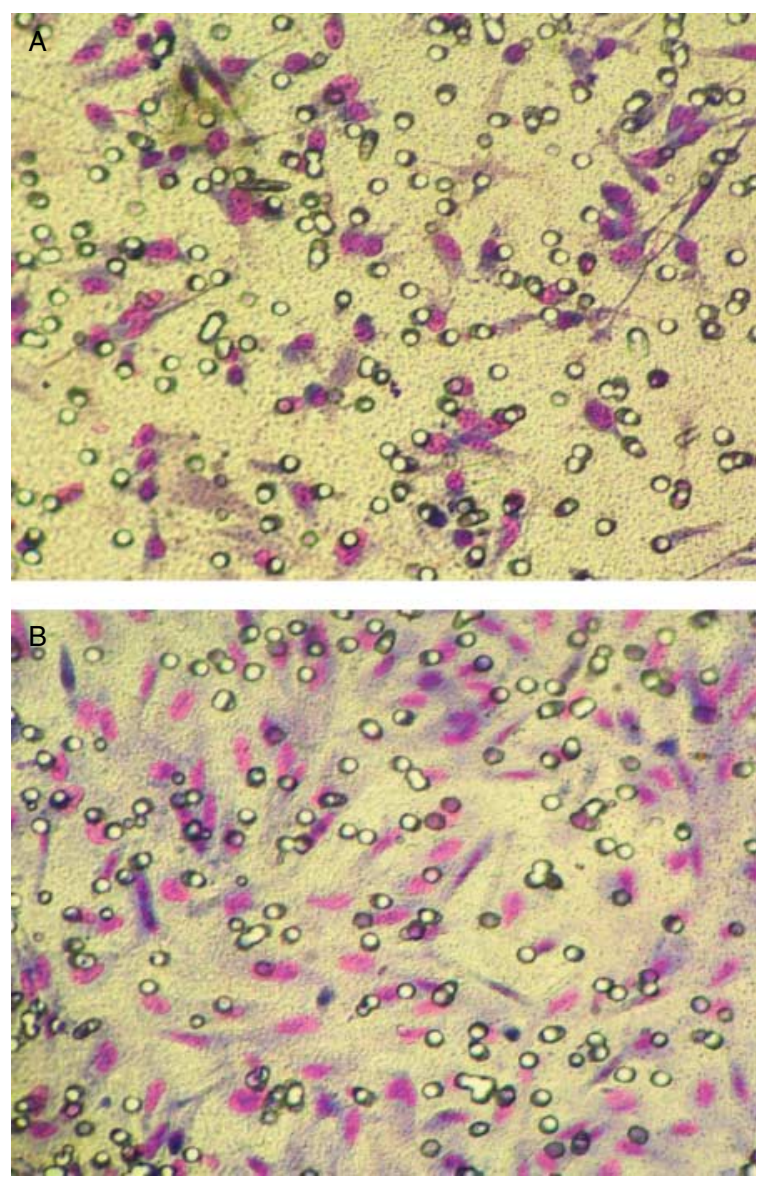

Figure 2

Representative chemotaxis experiment. Migrated endometrial stromal cells have been stained: the image shows cell migration in basal condition (A) and after stimulation with methanandamide $\left(10^{-5} \mathrm{M}\right)(\mathrm{B})$.

phenotype. This phenotype is characterised by the rapid dissolution of F-actin stress fibres, progressive localisation of F-actin towards the edge of the cell membrane and by the presence of numerous stress fibre arcs (Fig. 3; Hotulainen \& Lappalainen 2006, Gentilini et al. 2010). In addition, we also showed that methanandamide can regulate endometrial stromal cell motility by increasing electrical signal generated by $\mathrm{K}^{+}$channels that is an essential component of cellular migration. The ability of endocannabinoids to activate $\mathrm{K}^{+}$currents appears especially suggestive in this context because it is well known that external electric fields can also regulate embryo invasiveness and implantation (Schwab et al. 2008). The effects of endocannabinoids on endometrial cell migration have also been confirmed in a study from McHugh et al. (2011), although they suggest a CB1R-independent mechanism.
To date, there is only a single study that investigated the role of cannabinoids in the proliferation of endometrial cells. Leconte et al. (2010) showed that in vitro treatment with the agonist WIN 55212-2 has an antiproliferative effect mediated by a mechanism involving reduction of reactive oxygen species production and inactivation of the Akt pathway. Preliminary data from our laboratory confirm these findings. Indeed, high doses of methanandamide $\left(10^{-5} \mathrm{M}\right)$ influence endometrial stromal cell proliferation in a bimodal manner. The first 24-h stimulation increases cell proliferation, while prolonged treatments ( $48 \mathrm{~h}$ or more) lead to apoptosis (Fig. 4). The signalling pathways responsible for this bimodal effect have not been clarified yet, but it is tempting to speculate that prolonged treatment may lead to synthesis of apoptotic molecules such as ceramide (Ellert-Miklaszewska et al. 2013).
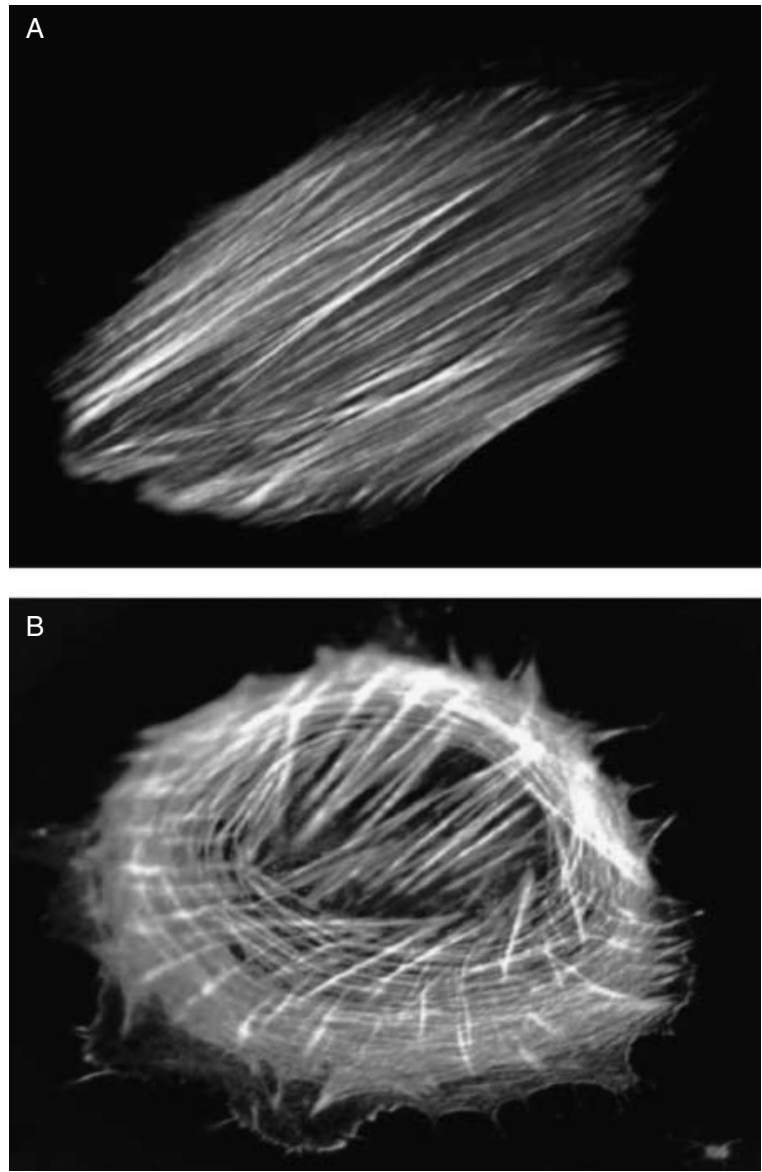

Figure 3

Effects of methanandamide $\left(10^{-5} \mathrm{M}\right)$ on actin cytoskeleton pattern of endometrial stromal cells. Untreated cells show a classic static phenotype (A). Treatment with methanandamide induces cytoskeleton rearrangements and a migratory phenotype (B).

Published by Bioscientifica Ltd. 

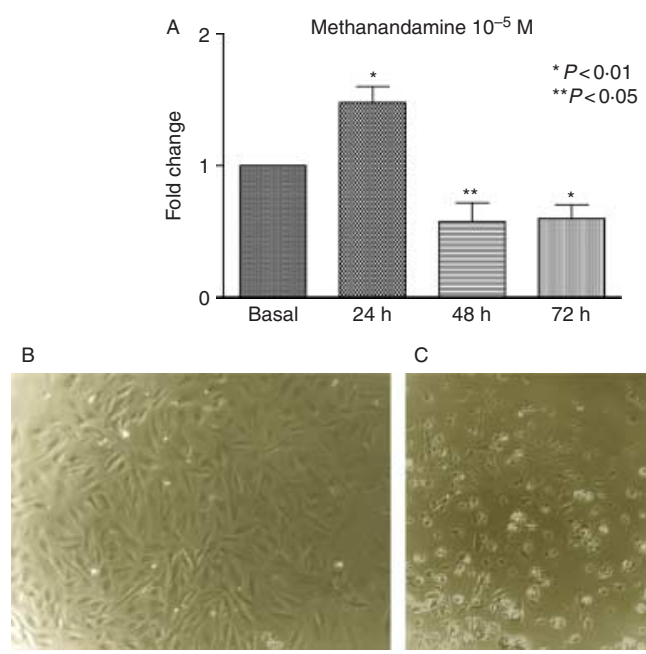

C

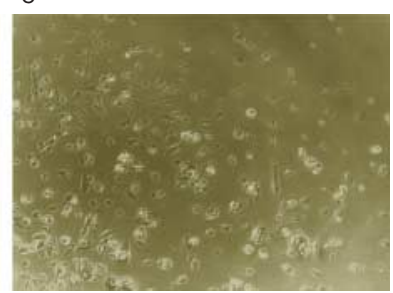

Figure 4

Effect of methanandamide $\left(10^{-5} \mathrm{M}\right)$ on endometrial stromal cell proliferation. Data are expressed as fold changes and are reported for 24,48 and $72 \mathrm{~h}$ treatments $(n=12)(A)$. (B) Endometrial stromal cells in basal condition. (C) Apoptotic endometrial stromal cells after 72-h stimulation with methanandamide.

Considering the possible role of the endocannabinoid system in regulating endometrial proliferation, Resuehr et al. investigated its involvement in endometriosis, a benign pathological condition characterised by deregulated endometrial cell proliferation and invasion. They demonstrated that expression of CB1R, at both the mRNA and protein level, is lower in eutopic endometrium of patients affected by endometriosis compared with that observed in samples obtained from control healthy women. This reduced CB1R expression has been attributed to the effects of persistent environmental toxicants and interleukin- $1 \alpha$ that induce a progesterone resistance phenotype in patients affected by the disease (Resuehr et al. 2012). Thus, it is possible to speculate that reduced cannabinoid signalling might underlie the enhanced proliferative capacity of endometriotic lesions.

\section{Conclusions}

As summarised in Fig. 5, endocannabinoids exert important actions in female reproductive organs. Their biological activities include regulation of oocyte and follicle maturation, embryo transport through the oviduct and implantation of the blastocyst. Impairment of the endocannabinoid system has been associated with pathological conditions involving these organs. In addition, it has recently emerged that endocannabinoids also regulate endometrial plasticity modulating endometrial cell migration and proliferation. Although these last effects certainly need to be better elucidated, we feel that the endocannabinoid system may represent an important task for researchers dealing with diseases of the female reproductive system characterised by increased invasiveness and proliferation of the endometrium. Among these diseases, endometrial cancer does certainly have a primary role, but also benign pathologies such as endometriosis could benefit from the results of such researches. Indeed,

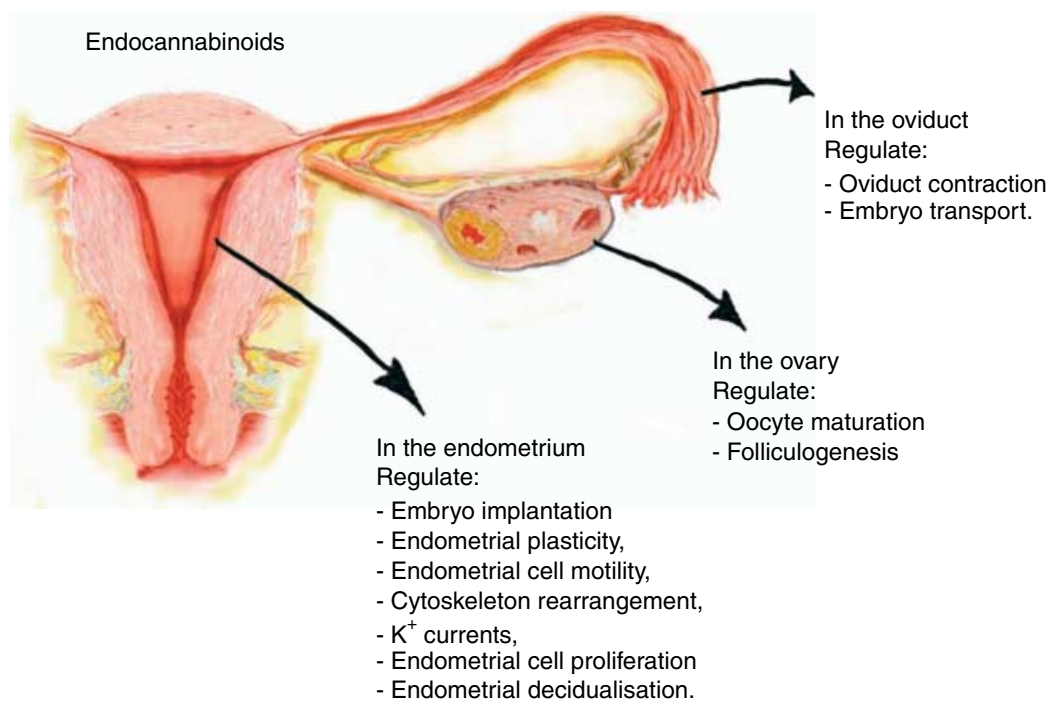

Figure 5

Overview of the most important biological activities of endocannabinoids in the female reproductive organs.

http://www.jme.endocrinology-journals.org DOI: $10.1530 / J M E-12-0182$ (c) 2013 Society for Endocrinology Printed in Great Britain
Published by Bioscientifica Ltd. 
the evaluation of chemical compounds acting on the endocannabinoid system will pave the way to develop alternative pharmacological strategies for a disease that, at present, heavily relies on surgical treatments.

\section{Declaration of interest}

The authors declare that there is no conflict of interest that could be perceived as prejudicing the impartiality of the review.

\section{Funding}

The authors have received support from the Istituto Auxologico Italiano.

\section{References}

Adashi EY, Jones PB \& Hsueh AJ 1983 Direct antigonadal activity of cannabinoids: suppression of rat granulosa cell functions. American Journal of Physiology 244 E177-E185.

Ahren B 2009 Islet G protein-coupled receptors as potential targets for treatment of type 2 diabetes. Nature Reviews. Drug Discovery 8 369-385. (doi:10.1038/nrd2782)

Alessandro R \& Kohn EC 2002 Signal transduction targets in invasion. Clinical \& Experimental Metastasis 19 265-273. (doi:10.1023/ A:1015547804511)

Anand-Apte B \& Zetter B 1997 Signalling mechanisms in growth factor stimulated cell motility. Stem Cells 15 259-267. (doi:10.1002/stem. 150259)

Battista N, Gasperi V, Fezza F \& Maccarrone M 2005 The anandamide membrane transporter and the therapeutic implications of its inhibition. Therapy 2 141-150. (doi:10.2217/14750708.2.1.141)

Battista N, Pasquariello N, Di Tommaso M \& Maccarrone M 2008 Interplay between endocannabinoids, steroids and cytokines in the control of human reproduction. Journal of Neuroendocrinology 20 82-89. (doi:10.1111/j.1365-2826.2008.01684.x)

Bellocchio L, Vicennati V, Cervino C, Pasquali R \& Pagotto U 2007 The endocannabinoid system in the regulation of cardiometabolic risk factors. American Journal of Cardiology 100 7P-17P. (doi:10.1016/j. amjcard.2007.10.009)

Bermudez-Siva FJ, Serrano A, Diaz-Molina FJ, Vera IS, Juan-Pico P, Nadal A, Fuentes E \& de Fonseca FR 2006 Activation of cannabinoid CB1 receptors induces glucose intolerance in rats. European Journal of Pharmacology 531 282-284. (doi:10.1016/j.ejphar.2005.12.016)

Das SK, Paria BC, Chakraborty I \& Dey SK 1995 Cannabinoid ligandreceptor signaling in the mouse uterus. PNAS 92 4332-4336. (doi:10.1073/pnas.92.10.4332)

Day TA, Rakhshan FR, Deutsch DG \& Baker EL 2001 Role of fatty acid amide hydrolase in the transport of endogenous cannabinoid anandamide. Molecular Pharmacology 59 1369-1375.

Devane WA, Dysarz FA III, Johnson MR, Melvin LS \& Howlett AC 1988 Determination and characterization of a cannabinoid receptor in the rat brain. Molecular Pharmacology 34 605-613.

Diaz-Laviada J \& Ruiz-Llorente I 2005 Signal transduction activated by cannabinoid receptors. Mini Reviews in Medicinal Chemistry 5 619-630. (doi:10.2174/1389557054368808)

Ellert-Miklaszewska A, Ciechomska I \& Kaminska B 2013 Cannabinoid signaling in glioma cells. Advances in Experimental Medicine and Biology 986 209-220.

El-Talatini MR, Elson JC, Taylor AH \& Konje JC 2007 The endocannabinoid, anandamide, is involved in human folliculogenesis and oocyte maturation during IVF treatment. 2nd SGI International Summit in

http://www.jme.endocrinology-journals.org DOI: $10.1530 / J M E-12-0182$
(C) 2013 Society for Endocrinology Printed in Great Britain
Reproductive medicine-From embryo and endometrium to implantation, Valencia, Spain, P2. 59p.

El-Talatini MR, Taylor AH \& Konje JC 2008 Longitudinal study showing the relationship between anandamide and sex steroids and gonadotrophin hormones in women. In: 18th Annual Symposium of the International Cannabinoid Research Society, Aviemore, Scotland, UK. 45p.

El-Talatini MR, Taylor AH, Elson JC, Brown L, Davidson AC \& Konje JC 2009 Localisation and function of the endocannabinoid system in the human ovary. PLOS ONE 4 e4579. (doi:10.1371/journal.pone.0004579)

Friedl P \& Wolf K 2003 Tumour-cell invasion and migration: diversity and escape mechanisms. Nature Reviews. Cancer 3 362-374. (doi:10.1038/ nrc1075)

Gambineri A, Pelusi C, Manicardi E, Vicennati V, Cacciari M, Morselli Labate AM, Pagotto U \& Pasquali R 2004 Glucose intolerance in a large cohort of Mediterranean women with polycystic ovary syndrome. Phenotype and associated factors. Diabetes 53 2353-2358. (doi:10.2337/diabetes.53.9.2353)

Gasperi V, Fezza F, Pasquariello N, Bari M, Oddi S, Finazzi-Agrò A \& Maccarrone M 2007 Endocannabinoids in adipocytes during differentiation and their role in glucose uptake. Cellular and Molecular Life Sciences 64 219-229. (doi:10.1007/s00018-006-6445-4)

Gentilini D, Besana A, Vigano P, Dalino P, Vignali M, Melandri M, Busacca M \& Di Blasio AM 2010 The Endocannabinoid system regulates migration of endometrial stromal cells via cannabinoid receptor 1 through the activation of PI3K and ERK1/2 pathways. Fertility and Sterility 93 2588-2593. (doi:10.1016/j.fertnstert.2010.02.006)

Guzeloglu-Kayisli O, Kayisli UA, Luleci G \& Arici A 2004 In vivo and in vitro regulation of Akt activation in human endometrial cells is estrogen dependent. Biology of Reproduction 7 714-721. (doi:10.1095/biolreprod. 104.027235)

Habayeb OM, Bell SC \& Konje JC 2002 Endogenous cannabinoids: metabolism and their role in reproduction. Life Sciences 70 1963-1977. (doi:10.1016/S0024-3205(01)01539-9)

Heilman RD, Reo RR \& Hahn DW 1976 Changes in the sensitivity of adrenergic receptors in the oviduct during early gestation in the rabbit. Fertility and Sterility 27 426-430.

Hermann A, Kaczocha M \& Deutsch DG 2006 2-Arachidonoylglycerol (2-AG) membrane transport: history and outlook. AAPS Journal 8 E409-E412.

Hillard CJ \& Jarrajan A 2003 Cellular accumulation of anandamide: consensus and controversy. British Journal of Pharmacology 140 802-808. (doi:10.1038/sj.bjp.0705468)

Ho WS, Barrett DA \& Randall MD 2008 "Entourage" effects of $\mathrm{N}$-palmitoylethanolamide and $\mathrm{N}$-oleoylethanolamide on vasorelaxation to anandamide occur though TRPV1 receptors. British Journal of Pharmacology 155 837-846. (doi:10.1038/bjp.2008.324)

Hotulainen P \& Lappalainen P 2006 Stress fibers are generated by two distinct actin assembly mechanisms in motile cells. Journal of Cell Biology 173 383-394. (doi:10.1083/jcb.200511093)

Howe GR \& Black DL 1973 Autonomic nervous system and oviduct function in the rabbit. I. Hormones and contraction. Journal of Reproduction and Fertility 33 425-430.

Howlett AC, Barth F, Bonner TI, Cabral G, Casellas P, Devane WA, Felder CC, Herkenham M, Mackie K, Martin BR et al. 2002 International Union of Pharmacology. XXVII. Classification of cannabinoid receptors. Pharmacological Reviews 54 161-202. (doi:10.1124/pr.54.2.161)

Huang SM, Bisogno T, Trevisani M, Al-Hayani A, De Petrocellis L, Fezza F, Tognetto M, Petros TJ, Krey JF, Chu CJ et al. 2002 An endogenous capsaicin-like substance with high potency at recombinant and native vanilloid VR1 receptors. PNAS 98 8400-8405. (doi:10.1073/pnas. 122196999)

Karasu T, Marczylo TH, Maccarone M \& Konje JC 2011 The role of sex steroid hormones, cytokines and the endocannabinoid system in female fertility. Human Reproduction Update 17 347-361. (doi:10.1093/ humupd/dmq058) 
Katona I \& Freund TF 2008 Endocannabinoid signalling as a synaptic circuit breaker in neurological disease. Nature Medicine 14 923-930. (doi:10.1038/nm.f.1869)

Kessler CA, Moghadam KK, Schroeder JK, Buckley AR, Brar AK \& Handwerger S 2005 Cannabinoid receptor I activation markedly inhibits human decidualization. Molecular and Cellular Endocrinology 229 65-74. (doi:10.1016/j.mce.2004.09.007)

Klein TW 2005 Cannabinoid-based drugs as anti-inflammatory therapeutics. Nature Reviews. Immunology 5 400-411. (doi:10.1038/nri1602)

Klonoff-Cohen HS, Natarajan L \& Chen RV 2006 A prospective study of the effects of female and male marijuana use on in vitro fertilization (IVF) and gamete intrafallopian transfer (GIFT) outcomes. American Journal of Obstetrics and Gynecology 194 369-376. (doi:10.1016/j.ajog. 2005.08.020)

Lauckner JE, Jensen JB, Chen HY, Lu HC, Hille B \& Mackie K 2008 GPR55 is a cannabinoid receptor that increases intracellular calcium and inhibits M current. PNAS 105 2699-2704. (doi:10.1073/pnas.0711278105)

Leconte M, Nicco C, Ngo C, Arkwright S, Chereau C, Guibourdenche J Weill B, Chapron C, Dousset B \& Batteux F 2010 Antiproliferative effects of cannabinoid agonists on deep infiltrating endometriosis. American Journal of Pathology 177 2963-2970. (doi:10.2353/ajpath. 2010.100375)

Ligresti A, Cascio MG \& Di Marzo V 2005 Endocannabinoid metabolic pathways and enzymes. Current Drug Targets. CNS and Neurological Disorders 4 615-623. (doi:10.2174/156800705774933104)

Liu J, Wang L, Harvey-White J, Osei-Hyiaman D, Razdan R, Gong Q, Chan AC, Zhou Z, Huang BX, Kim HY et al. 2006 A biosynthetic pathway for anandamide. PNAS 103 13345-13350. (doi:10.1073/ pnas.0601832103)

Maccarone M 2009 Endocannabinoids: friends and foes of reproduction. Progress in Lipid Research 48 344-354. (doi:10.1016/j.plipres.2009. 07.001)

Maccarrone M, Bisogno T, Valensise H, Lazzarin N, Fezza F, Manna C, Di Marzo V \& Finazzi-Agrò A 2002 Low fatty acid amide hydrolase and high anandamide levels are associated with failure to achieve ongoing pregnancy after IVF and embryo transfer. Molecular Human Reproduction 8 188-195. (doi:10.1093/molehr/8.2.188)

Matsusa LA, Lolait SJ, Brownstein MJ, Young AC \& Bonner TI 1990 Structure of a cannabinoid receptor and functional expression of the cloned cDNA. Nature 346 561-564. (doi:10.1038/346561a0)

McFarland MJ, Porter AC, Rakhshan FR, Ravat DS, Gibbs RA \& Baker EL 2004 A role for caveolae/lipid rafts in the uptake and recycling of the endogenous cannabinoid anandamide. Journal of Biological Chemistry 279 41991-41997. (doi:10.1074/jbc.M407250200)

McHugh DJ, Page Dunn E \& Bradshaw HB 2011 Delta(9)-THC and $\mathrm{N}$-arachidonyl glycine are full agonists at GPR18 and cause migration in the human endometrial cell line, HEC-1B. British Journal of Pharmacology 8 2411-2413.

McKinney MK \& Cravatt BF 2005 Structure and function of fatty acid amide hydrolase. Annual Review of Biochemistry 74 411-432. (doi:10.1146/ annurev.biochem.74.082803.133450)

Mitchell MD, Sato TA, Wang A, Keelan JA, Ponnampalam AP \& Glass M 2008 Cannabinoids stimulate prostaglandin production by human gestational tissue through a tissue- and CBr1-receptor-specific mechanism. American Journal of Physiology. Endocrinology and Metabolism 294 352-356. (doi:10.1152/ajpendo.00495.2007)

Mueller BA, Daling JR, Weiss NS \& Moore DE 1990 Recreational drug use and the risk of primary infertility. Epidemiology 1 195-200. (doi:10.1097/00001648-199005000-00003)

Munro S, Thomas KL \& Abu-Shaar M 1993 Molecular characterization of a peripheral receptor for cannabinoids. Nature 365 61-65. (doi:10.1038/ 365061a0)

Murphy LL, Steger RW, Smith MS \& Bartke A 1990 Effects of $\Delta^{9}$-tetrahydrocannabinol, cannabinol and cannabidiol, alone and in combinations,. on luteinizing hormone and prolactin release and on hypothalamic

http://www.jme.endocrinology-journals.org DOI: 10.1530/JME-12-0182
(C) 2013 Society for Endocrinology Printed in Great Britain neurotransmitters in the male rat. Neuroendocrinology 52 316-321. (doi:10.1159/000125604)

Nir I, Ayalon D, Tsafriri A, Cordova T \& Lindner HR 1973 Suppression of the cyclic surge of luteinizing hormone secretion and ovulation in the rat by D1-tetrahydrocannabinol. Nature 243 470-471. (doi:10.1038/ 243470a0)

Nogueiras R, Diaz-Arteaga A, Lockie SH, Velásquez DA, Tschop J, López M, Cadwell CC, Diéguez C \& Tschöp MH 2009 The endocannabinoid system: role in glucose and energy metabolism. Pharmacological Research 60 93-98. (doi:10.1016/j.phrs.2009.04.004)

Okamoto Y, Morishita J, Tsuboi K, Tonai T \& Ueda N 2004 Molecular characterization od a phospholipase D generating anandamide and its congeners. Journal of Biological Chemistry 279 5298-5305. (doi:10.1074/ jbc.M306642200)

O'Sullivan SE 2007 Cannabinoids go nuclear: evidence for activation of peroxisome proliferators-activated receptors. British Journal of Pharmacology 152 576-578. (doi:10.1038/sj.bjp.0707423)

Pacher P, Mukhopadhyay P, Mohhanraj R, Godlewsi G, Batkai S \& Kunos G 2008 Modulation of the endocannabinoid system in cardiovascular disease: therapeutic potential and limitation. Hypertension 52 601-607. (doi:10.1161/HYPERTENSIONAHA.105.063651)

Pagotto U, Marsicano G, Cota D, Lutz B \& Pasquali R 2006 The emerging role of endocannabinoid system in endocrine regulation and energy balance. Endocrine Reviews 27 73-100. (doi:10.1210/er.2005-0009)

Paria BC, Zhao X, Wang J, Das SK \& Dey SK 1999 Fatty-acid amide hydrolase is expressed in the mouse uterus and embryo during the periimplantation period. Biology of Reproduction 60 1151-1157. (doi:10.1095/ biolreprod60.5.1151)

Paria BC, Song H, Wang X, Schmid PC, Krebsbach RJ, Schmid HH, Bonner TI, Zimmer A \& Dey SK 2001 Dysregulated cannabinoid signaling disrupts uterine receptivity for embryo implantation. Journal of Biological Chemistry 276 20523-20528. (doi:10.1074/jbc. M100679200)

Pasquali R, Gambineri A \& Pagotto U 2006 The impact of obesity on reproduction in women with polycystic ovary syndrome. BJOG: an International Journal of Obstetrics and Gynaecology 113 1148-1159. (doi:10.1111/j.1471-0528.2006.00990.x)

Pasquali R, Patton L \& Gambineri A 2007 Obesity and infertility. Current Opinion in Endocrinology, Diabetes, and Obesity 14 482-487. (doi:10.1097/MED.0b013e3282f1d6cb)

Prescott SM \& Majerus PW 1983 Characterization of 1,2-diacylglycerol hydrolysis in human platelets. Demonstration of an arachidonoylmonoacylglycerol intermediate. Journal of Biological Chemistry 258 764-769.

Resuehr D, Glore DR, Taylor HS, Bruner-Tran KL \& Osteen KG 2012 Progesterone dependent regulation of endometrial cannabinoid receptor type 1 (CB1-R) expression is disrupted in women with endometriosis and in isolated stromal cells exposed to 2,3,7,8-tetrachlorodibenzo-p-dioxin (TCDD). Fertility and Sterility 98 948.e1-956.e1. (doi:10.1016/j.fertnstert.2012.06.009)

Ross RA 2009 The enigmatic pharmacology of GPR55. Trends in Pharmacological Sciences 30 156-163. (doi:10.1016/j.tips.2008.12.004)

Rouzer CA \& Marnett LJ 2008 Non-redundant functions of cyclooxygenases: oxygenation of endocannabinoids. Journal of Biological Chemistry 283 8065-8069. (doi:10.1074/jbc.R800005200)

Salamonsen LA 2003 Tissue injury and repair in the female human reproductive tract. Reproduction 125 301-311. (doi:10.1530/rep. $0.1250301)$

Schmid PC, Paria BC, Krebsbach RJ, Schmid HH \& Dey SK 1997 Changes in anandamide levels in mouse uterus are associated with uterine receptivity for embryo implantation. PNAS 94 4188-4192. (doi:10.1073/pnas.94.8.4188)

Schuel H, Burkman LJ, Lippes J, Crickard K, Forester E, Piomelli D \& Giuffrida A $2002 \mathrm{~N}$-acylethanolamines in human reproductive fluids. Chemistry and Physics of Lipids 121 211-227. (doi:10.1016/S0009. 3084(02)00158-5) 
Schwab A, Hanley P, Fabian A \& Stock C 2008 Potassium channels keep mobile cells on the go. Physiology 23 212-220. (doi:10.1152/physiol. 00003.2008)

Simon GM \& Cravatt BF 2006 Endocannabinoid biosynthesis proceeding through glycerophospho-N-acyl ethanolamine and a role for alpha7beta hydrolase 4 in this pathway. Journal of Biological Chemistry $\mathbf{2 8 1}$ 26465-26472. (doi:10.1074/jbc.M604660200)

Snider NT, Sikora MJ, Sridar C, Feuerstein TJ, Rae JM \& Hollenberg PF 2008 The endocannabinoid anandamide is a substrate for the human polymorphic cytochrome P450 2D6. Journal of Pharmacology and Experimental Therapeutics 327 538-545. (doi:10.1124/jpet.108.141796)

Starowicz K, Nigam S \& Di Marzo V 2007 Biochemistry and pharmacology of endovanilloids. Pharmacology \& Therapeutics 114 13-33. (doi:10.1016/j.pharmthera.2007.01.005)

van der Stelt M, van Kuik JA, Bari M, van Zadelhoff G, Leeflang BR, Veldink GA, Finazzi-Agrò A, Vliegenthart JF \& Maccarrone M 2002 Oxygenated metabolites of anandamide and 2-arachidonoyldlycerol: conformational analysis and interaction with cannabinoid receptors, membrane transporter and fatty acid amide hydrolase. Journal of Medicinal Chemistry 45 3709-3720. (doi:10.1021/jm020818q)

Taylor AH, Abbas MS, Habiba MA \& Konje JC 2010a Histomorphometric evaluation of cannabinoid receptor and anandamide modulating enzyme expression in the human endometrium through the menstrual cycle. Histochemistry and Cell Biology 133 557-565. (doi:10.1007/ s00418-010-0695-9)

Taylor AH, Amoako AA, Bambang K, Karasu T, Gebeh A, Lam PM, Marzcylo TH \& Konje JC 2010b Endocannabinoids and pregnancy. Clinica Chimica Acta 411 921-930. (doi:10.1016/j.cca.2010.03.012)

Wang H, Guo Y, Wang D, Kingsley PJ, Marnett LJ, Das SK, DuBois RN \& Dey SK 2004 Aberrant cannabinoid signaling impairs oviductal transport of embryos. Nature Medicine 10 1074-1080. (doi:10.1038/ nm1104)

Wang H, Dey SK \& Maccarrone M 2006 Jekyll and Hyde: two faces of cannabinoid signalling in male and female fertility. Endocrine Reviews 27 427-428. (doi:10.1210/er.2006-0006)

Wilkes S \& Murdoch A 2009 Obesity and female fertility: a primary care perspective. Journal of Family Planning and Reproductive Health Care $\mathbf{3 5}$ 181-185. (doi:10.1783/147118909788707995)

Zain MM \& Norman RJ 2008 Impact of obesity on female fertility and fertility treatment. Women's Health 4 183-194. (doi:10.2217/17455057. 4.2.183)

Zygmunt PM, Hogestatt ED, Julius D \& Di Marzo V 2000 Anandamide: the other side of the coin. Trends in Pharmacological Sciences 21 43-44. (doi:10.1016/S0165-6147(99)01430-3)

Received in final form 22 November 2012

Accepted 23 November 2012

Accepted Preprint published online 23 November 2012
(C) 2013 Society for Endocrinology Printed in Great Britain
Published by Bioscientifica Ltd. 